\title{
Impact of Training on Employees' Performance: A Case Study of Selected Private Sectors Companies in Oman
}

\author{
Dr. Sufian Eltayeb Mohamed Abdel-Gadir ${ }^{1 *}$, Nabila Salim Hamed AL-Jahwari ${ }^{2}$ \\ ${ }^{I}$ College of Law, Sultan Qaboos University, P.O. Box 50, Al-khod P.C. 123, Muscat, Sultanate of Oman \\ ${ }^{2}$ Rustaq, CAS, Ministry of Higher Education, Oman, P.O. Box: 10 - Postal Code: 329
}

*Corresponding Author: Dr. Sufian Eltayeb Mohamed Abdel-Gadir, Assistant Professor in Economics and Head, Quality Assurance \& Academic Accreditation Unit, College of Law, Department of Public Law, Room 0038, Block G, Sultan Qaboos University, P.O. Box 50, Al-khod P.C. 123, Muscat, Sultanate of Oman

\begin{abstract}
This article examines the Impact of training on employees' performance: A Case study of selected private sectors companies in Oman. Data was collected through an administered questionnaire with a sample of 46 respondents selected randomly from five companies: Sohar Aluminum, Stomo Company, Suhail Bahwan Group (Holding) LLC, Ooredoo Company and Oman Formaldehyde Chemical Company.

The findings shows the success of the training program on improving the employee's abilities, skills, productivity, efficiency. The results also showed that respondents agree with the relevance of the training program to the nature of their work.

The study also showed the employees' views on company attitudes towards training programs. The respondents confirmed that their companies believe that training is the best way to convey new skills to employees. Additionally, their companies have a clear policy for training shown by implementing a proper mechanism for adjustment, review and evaluation of all training programs. To sum up, the study recommended that firm should provide an adequate working environment to ensure that workers have high levels of commitment.
\end{abstract}

Keywords: Training Programs, Employees 'performance, private companies, Oman

\section{INTRODUCTION}

This study emphasizes on the importance of training programs on raising employees' performance. In general, all organizations aim to achieve high productivity in order to generate maximum profits and benefits. Actually, there are different ways to raise the productivity of any organization but the most significant one is through training programs. The performance of any organization is dependent on the quality of its labour force. Training programs help workers to develop their success and efficiency at the workplaces. As well, training can help worker to acquire the basic skills that he wants for a certain position. Nowadays, many companies try to provide many training programs for their employees in order to achieve certain goals. Many researches including Colombo and Stanca (2008), Sepulveda (2005) and Konings \& Vanormelingen, (2009), showed that training is a fundamental and effectual instrument in successful accomplishment of the firm's goals and objectives, resulting in higher performance and productivity of the organization.

Training programs help employees to address their weaknesses. As we know, some employees face some difficulties at their workplaces that prevent them to reach optimum level of job satisfaction. Training programs can reduce these weaknesses through improving their skills and abilities. Moreover, these kinds of programs contribute in the improvement of workers achievements. According to (McDowall, A. and Saunders, M.N.K. (2010)), the recognition of the importance of training in recent years has been heavily influenced by the intensification of competition and the relative success of organizations where investment in employee development is considerably emphasized. In addition, training is seen as a useful means of coping with changes fostered by technological innovation; market competition, organizational structuring and most importantly it plays 
a key role to enhance employee performance. Training facilitates the updating of skills and lead to increase commitment, well-being, and sense of belonging, thus directly strengthening the organization's competitiveness (Acton and Golden, 2002; Karia and Ahmad, 2000; Karia, 1999)

The present study intends to investigate the impact of the training programs on employees' performance at private sector in Oman by using analytical and descriptive methods.

\section{Statement of The Problem}

There is no doubt that organizations worldwide are striving for success and outcompeting those in the same industry. In order to do so, organizations have to obtain and utilize their human resources effectively On the other hand, many companies and organization are not able to allocate adequate fund to provide training for their employees. So the result will be poor work force development and consequently, poor organizational performance. Given the above, it becomes necessary to determine the relationship between training and employee performance in Oman' private sector companies.

\section{OBJECTIVE OF THE STUDY}

The main objective of this study is to investigate the impact of training on employee performance in selected Omani private sector companies. Other objectives that drawn from the main objective are:

1. To figure out employees' views on company attitudes towards training programs.

2. To find out if there is an evaluation system for employees at institution after training programs conducted.

3. To find out how training programs can affect positively on employees' productivity and performances.

\section{SIGNIFICANCE OF THE STUDY}

The significance of this study stem from the following points:

Firstly, it will highlight the importance of training programs that lead to higher workers' performance.

Secondly, it will also give insights to companies and firms to direct and structure their training programs in order to get more effective and efficient labor force..

Thirdly, it will also help the management of companies under studies to do future research on the effectiveness of training programs.

\section{SCOPE OF THE STUDY}

This study intended to show how training program affect employees performance in Omani private sector companies. The study conducted on five Omani companies. These companies are, Sohar Aluminum $^{1}$, Stomo Company ${ }^{2}$, Suhail Bahwan Group (Holding) LLC ${ }^{3}$, Ooredoo Company ${ }^{4}$ and Oman Formaldehyde Chemical Company ${ }^{5}$.

\section{STUDY RESEARCh QUESTIONS}

The study emphasizes on following research questions:

1. How does training program increases employee's performance?

2. How many Training programs offered to each employee per year in private sector?

3. Is there any evaluation for each employee at institution after training programs conducted?

\section{LITERATURE REVIEW}

\footnotetext{
${ }^{1}$ https://www.sohar-aluminium.com/

2 http://www.stomo.com.om/

${ }^{3}$ http://www.suhailbahwangroup.com

${ }^{4}$ https://www.ooredoo.om/AboutOoredoo/Corporate/AboutOoredoo.aspx

${ }^{5} \mathrm{http}$ ///www.omzest.com/companies/oman-formaldehyde-chemical-company-llc.html
} 
Employee training has recently become a vital business strategy not only to retain employees but also to create a skilled workforce for the future. Training provides many benefits for both employees and company if it is carefully planned and properly implemented. Many authors wrote about the importance of training, for example, Mozael, 2015, wrote, "Training is an on-going and continuous process which aimed to achieve better employee performance through improving employee attitude and the way employee behaved at work". To Nischithaa \& Rao, 2014, "training is an action of upgrading employee skills for a specific task". Afghan et al (2012), conducted study to examine the impact of training on employee performance in the telecommunication sector in Pakistan. Their study concludes that if organizations invest in right type of employee training it can enhance employee performance as well as competencies and skills. In addition, training is seen as a useful means of coping with changes fostered by technological innovation; market competition, organizational structuring and most importantly it plays a key role to enhance employee performance

Teresa Brannick, et al, (2002) conducted study on "Service Management Practice- Performance Model: A Focus on Training Practices". This study aimed to know the impacts of training programs on providing services to customers. The researchers were collected data from (143) services companies in Ireland. This study found that the training programs are contributing very well on the performance of employees in Service Company and these programs can improve their skills when offer various services to their customers. Finally, training programs can lead to satisfy customer's needs and wants and increase the productivity of the company.

Another study was conducted by Abdelgadir and Elbadri, (2001) on "Training Practices of Polish Banks: An Appraisal and Agenda for Improvement". This study aimed to know the training practices and activities in Boland Banks. The researchers were gathered information from (30) banks in Boland. Their study was focused on training activities that were involved many aspects like; determining the needs of training, developing training programs, evaluating the effectiveness of these programs. This study found that many of banks are ignoring the needs of training programs and the absence of evaluating training programs that reflect on employee's performances. Daniels, (2003) conducted study on " Employee Training: A Strategic Approach to Better Return on Investment". This study was done to know the returns that training programs add to the workers on banks. The researchers were collected data from (15) British banks. This study was revealed that training programs contribute significantly on improving employee's skills and knowledge, building an effective work team, achieving high level of quality and creating organizational culture that support organization's strategies and objectives. All these aspects can contribute on achieving good returns to invest on training programs.

According to William Coventry, (1968) training is a planned and ongoing process that aims to meet current and future training needs of workers in different organizations and firms. There are many benefits that training programs can add to employees at workplaces such as; increasing their knowledge and skills in the field of specialization, supporting their attitudes and understanding their functional duties. All these can contribute significantly on the worker's performances as well as, training programs lead to enhance and increase the crafts and productivity of the workers.

Khaled N. \& . Khaled N. Alshuwairek (2016), study the effectiveness of the training programs on employment performance at private sector companies in Saudi Arabia. The result of the study indicated that, all the variables are positively correlated to each other, also the total average value for domain reality of training was 3.47, which fall in the range of Likert scale between (3.41- 4.20), which also reflect the respondents agree with private sector companies provide effective training programs matching up with their expectations however there are some respondents disagreed about the comprehensiveness of training material and trainer motivate their trainees. The total average value for domain role of training programs for improving the employee's performance was 3.37 , which fall in the range of Likert scale between (2.61-3.40), which also reflect the respondents were neutral about the role of training programs. For improving the employee's performance at private 
sector companies in KSA however some respondents agreed about the training programs improve their skills and knowledge and assist them to solve their problems

Jihad Aldhyat, (1999), "Evaluate the effectiveness of training programs in the private training centers from the perspective of the trainees". The study aimed to know the effectiveness of training programs in the private training centers. Also, to know the methods and levels of evaluating training programs to determine its advantages and disadvantages. In addition, it aimed to know the effects of training programs on the worker's performance in Jordanian commercial banks. The results showed, that training centers and Jordanian commercial banks who were participated on training both were said that there is no evaluation after training to know the benefit that worker obtain when he participated in training programs. The researcher recommended the importance of evaluating the workers at workplaces after training programs to know if there is any benefit that worker gained from training or not.

Gasco, et.al, (2004) study " The Use of Information Technology in Training Human Resources: An Elearning Case Study". This study is conducted to know the effects of using information technology on human resources management practices especially training strategy in the Spanish telecommunications company. The results of the study showed that the using of information technology in training have positive effects such as increasing the active participation of trainees, better use of time management, better assess the effectiveness of training programs. The Spanish telecommunications company aimed to improve future training systems.

According to Cole (2002), training can achieve: high morale - employees who receive training have increased confidence and motivation; lower cost of production. Training eliminates risks because trained personnel are able to make better and economic use of material and equipment thereby reducing and avoiding waste; lower turnover. Training brings a sense of security at the workplace, which reduces labor turnover.

(Cooke, 2000). Kenney et al., (1992) stated that employee's performance is measured against the performance standards set by the organization. Good performance means how well employees performed on the assigned tasks. In every organization, there are some expectations from the employees with respect to their performance

\section{MeThodology}

Analytical and descriptive approach is adopted to assess the extent to which, training programs affect employees' performance. This entailed a survey of the views of employees who work in the selected private sector companies in Oman: Sohar Aluminum, Stomo Company, Suhail Bahwan Group (Holding) LLC, Ooredoo Company and Oman Formaldehyde Chemical Company .The survey was conducted through a self-administered questionnaire distributed in the five of the Sultanate's private companies mentioned above. Although 60 questionnaires were issued, only 46 were returned, a response rate of 76.67 per cent.

The questionnaire was subject to validity and reliability tests, using Alpha Kronbach, and showed a strong internal consistency reliability of 87.3 per cent. A five-point Likert scale was used in the questionnaire to measure respondents' views on training employees' performance. Responses were classified as 'strongly disagree', 'disagree', 'neutral', 'agree' and 'strongly agree', and coded 1, 2, 3, 4 and 5 respectively.

\section{RESUlts ANd DATA ANALYSIS}

\subsection{Demographic Profile of Respondents}

\subsubsection{Gender of the Respondents}

Regarding the demographic profile of the respondents who participated in the study, the results indicate that of the 46 respondents, there were 29 (63.0 per cent) males and 17 (37.0 per cent) females.

Table9.1.1. Gender of the Respondents

\begin{tabular}{|l|l|l|l}
\hline Frequency & Percent & Valid Percent & Cumulative \%
\end{tabular}


Impact of Training on Employees' Performance: A Case Study of Selected Private Sectors Companies in Oman

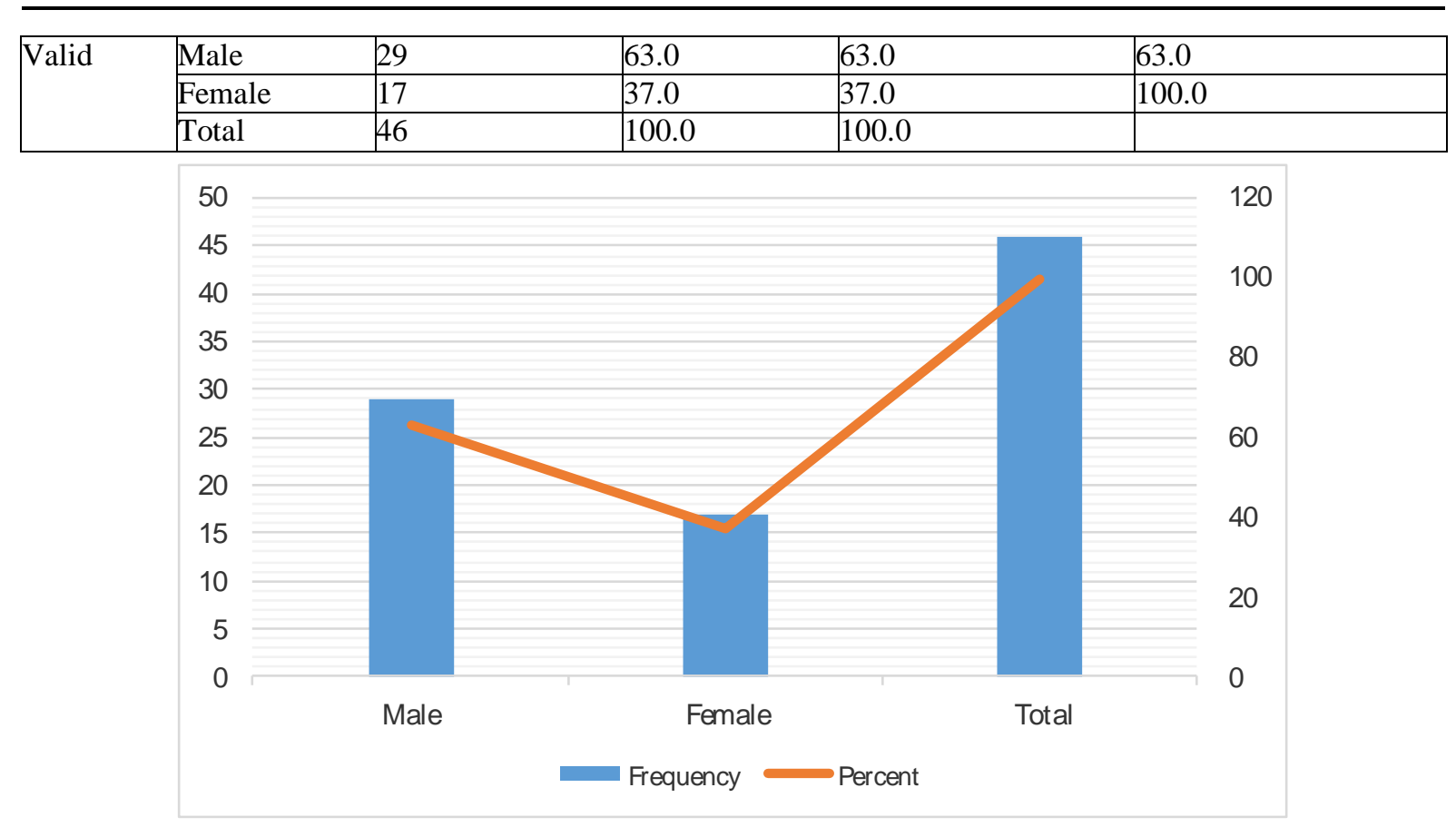

Figure9.1.1. Gender of the Respondents

Source: Authors' own calculation from the questionnaire survey

\subsubsection{Marital status of the Respondents}

Table 9.1.2 and Figure 9.1.2 shows the numbers of employees who responded and fill the questionnaire according to marital status. The researcher found that the numbers of employees who are single are 13 which represent 28.3 percent and the numbers of employees who are married are 33 which represent 71.7 percent So, the numbers of married employees who responded to questionnaire are more than single employees.

Table9.1.2. Marital status of the Respondents

\begin{tabular}{|l|l|l|l|l|l|}
\hline \multicolumn{2}{|c|}{} & Frequency & Percent & Valid Percent & Cumulative \% \\
\hline \multirow{4}{*}{ Valid } & Single & 13 & 28.3 & 28.3 & 28.3 \\
\cline { 2 - 6 } & Married & 33 & 71.7 & 71.7 & 100 \\
\cline { 2 - 6 } & Total & 46 & 100 & 100 & \\
\hline
\end{tabular}

Figure 9.1.2: Marital status of respondents

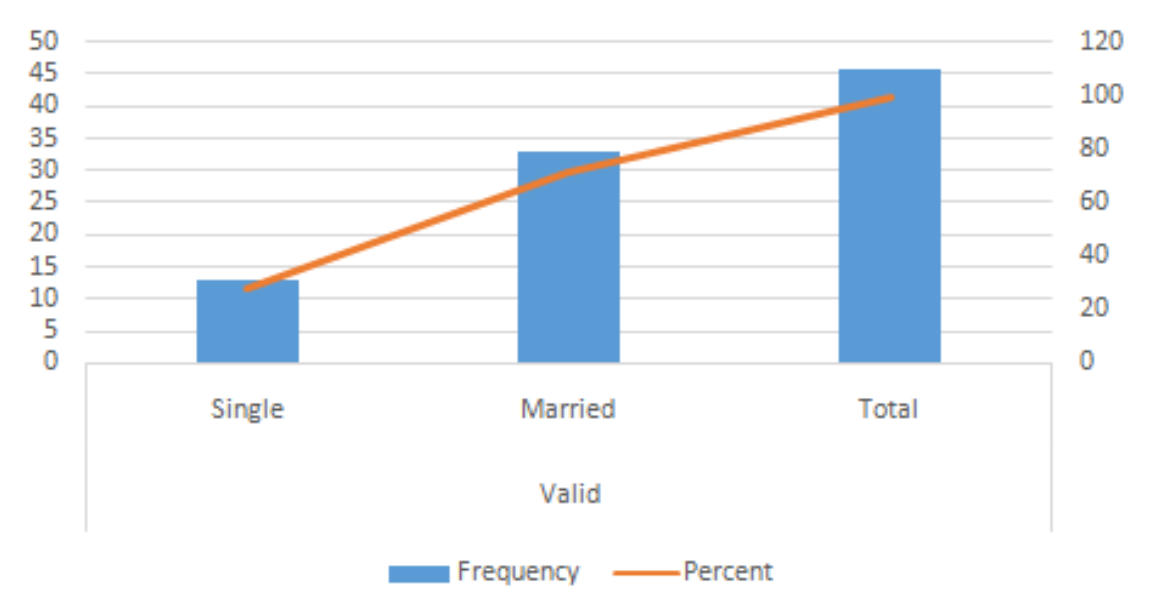

Source: Authors' own calculation from the questionnaire survey

9.1.3. To Ages of the Respondents 
Impact of Training on Employees' Performance: A Case Study of Selected Private Sectors Companies in Oman

In term of age, Table 9.1.3 and Figure 9.1.3 shows different ages of employees who responded to the questionnaire. The numbers of employees' respondents under 20 years are 6 (13\%), between 21-30 years are $23(50 \%$.), between 31-40 years are $11(23.9 \%$.) between 40 and above are $6(13 \%)$. So, the numbers of employees' respondents between 21-30 years are highest than other ages.

Table9.1.3. Ages of the Respondents

\begin{tabular}{|l|l|l|l|l|l|}
\hline \multicolumn{2}{|c|}{} & Frequency & Percent & Valid Percent & Cumulative \% \\
\hline Valid & Under 20 years & 6 & 13 & 13 & 13 \\
\cline { 2 - 6 } & $21-30$ years & 23 & 50 & 50 & 63 \\
\cline { 2 - 6 } & $31-40$ years & 11 & 23.9 & 23.9 & 87 \\
\cline { 2 - 6 } & 40 and above & 6 & 13 & 13 & 100 \\
\cline { 2 - 6 } & Total & 46 & 100 & 100 & \\
\hline
\end{tabular}

Figure 9.1.3: Ages of the respondents

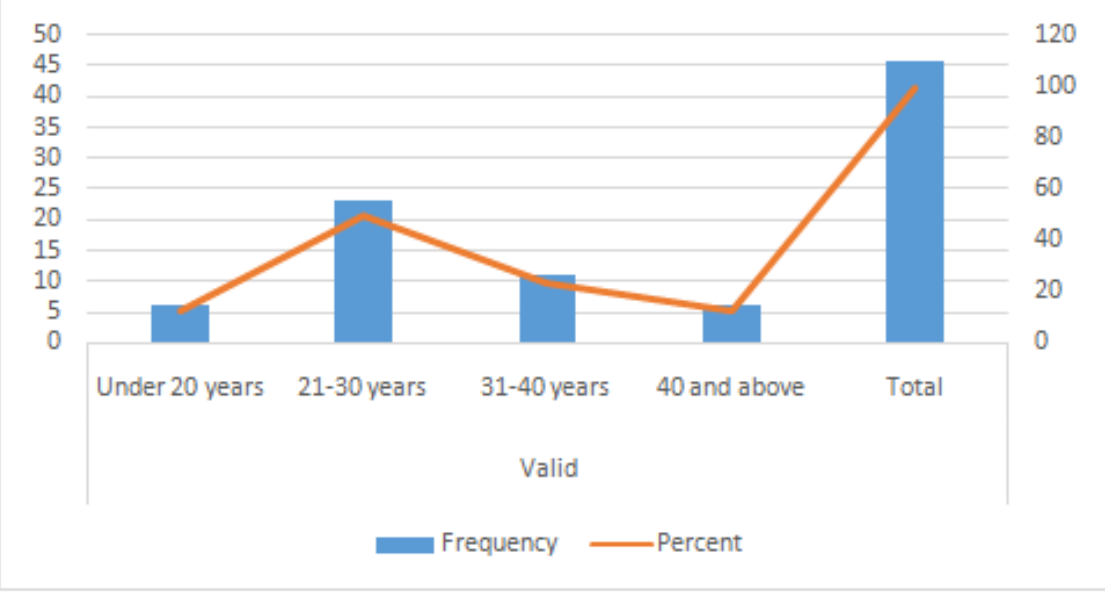

Source: Authors' own calculation from the questionnaire survey

\subsubsection{Academic and Professional Qualification of the Respondents}

Concerning their level of education, 10.9 percent had Secondary qualification, 45.7 percent had Diploma qualification, 28.3 had Bachelor' degree. 8.7 percent were Post-Graduates, and 6.5 percent for others qualification. Therefore, the numbers of employees' respondents who have Diploma qualification are more than other Academic and Professional Qualifications.

Table9.1.4. Academic and Professional Qualification of the Respondents

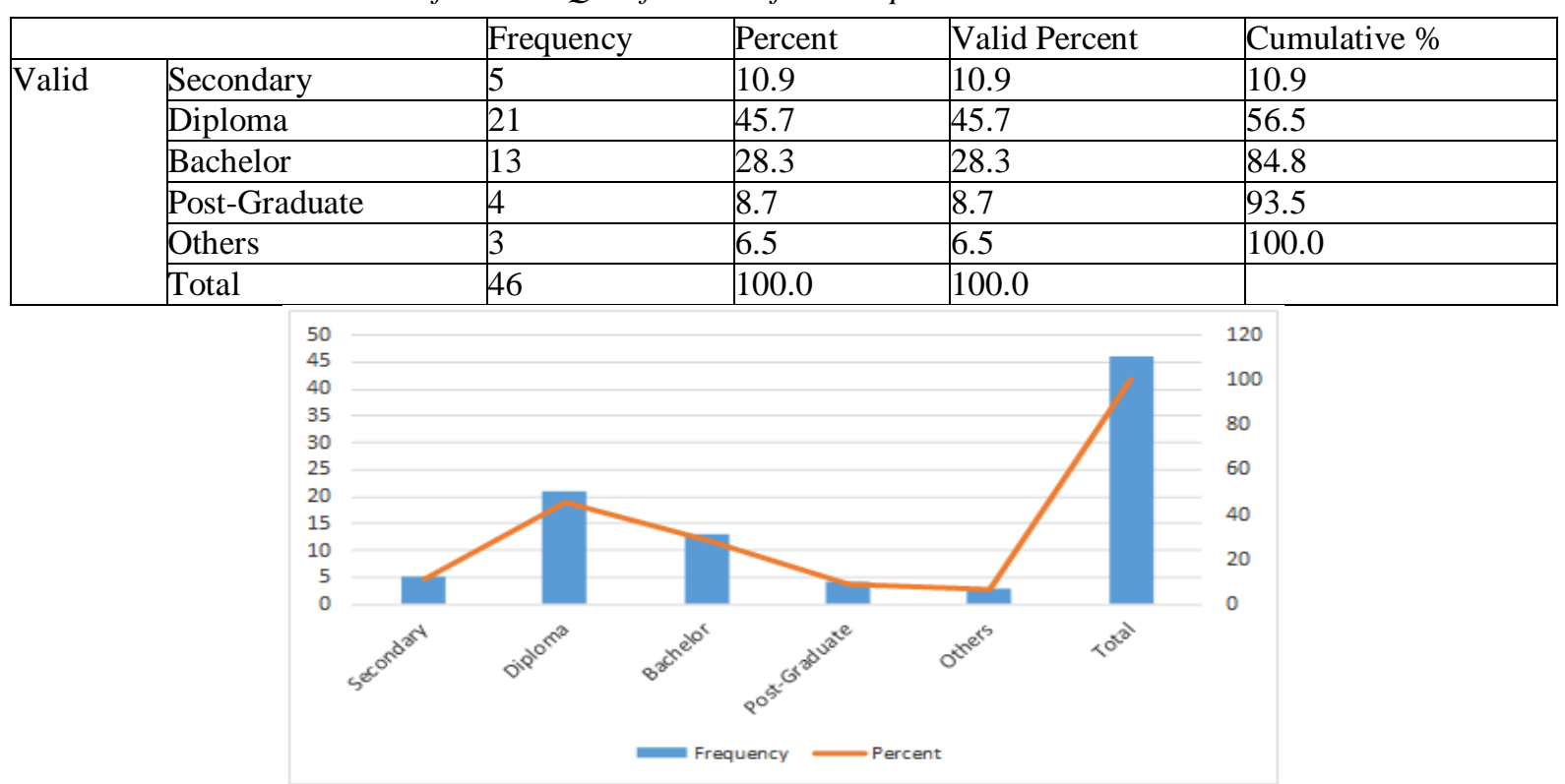

Figure9.1.4. Academic and Professional Qualification of the Respondents

Source: Authors' own calculation from the questionnaire survey 
Impact of Training on Employees' Performance: A Case Study of Selected Private Sectors Companies in Oman

\subsubsection{Work Experience of the Respondents}

Table 9.1.5 and figure 9.1.5 shows the years of experiences of the employees who are participated in the questionnaire. Firstly, the numbers of employees who have experiences less than 10 years are represent 71 percent. Secondly, the numbers of employees who have experiences between 10 and 20 years are 23 percent. Finally, the numbers of employees who have experiences over 20 years represent 4.3\%. Therefore, our sample consists mainly of employees who have less than 10 years of experiences.

Table9.1.5. Work Experience of the Respondents

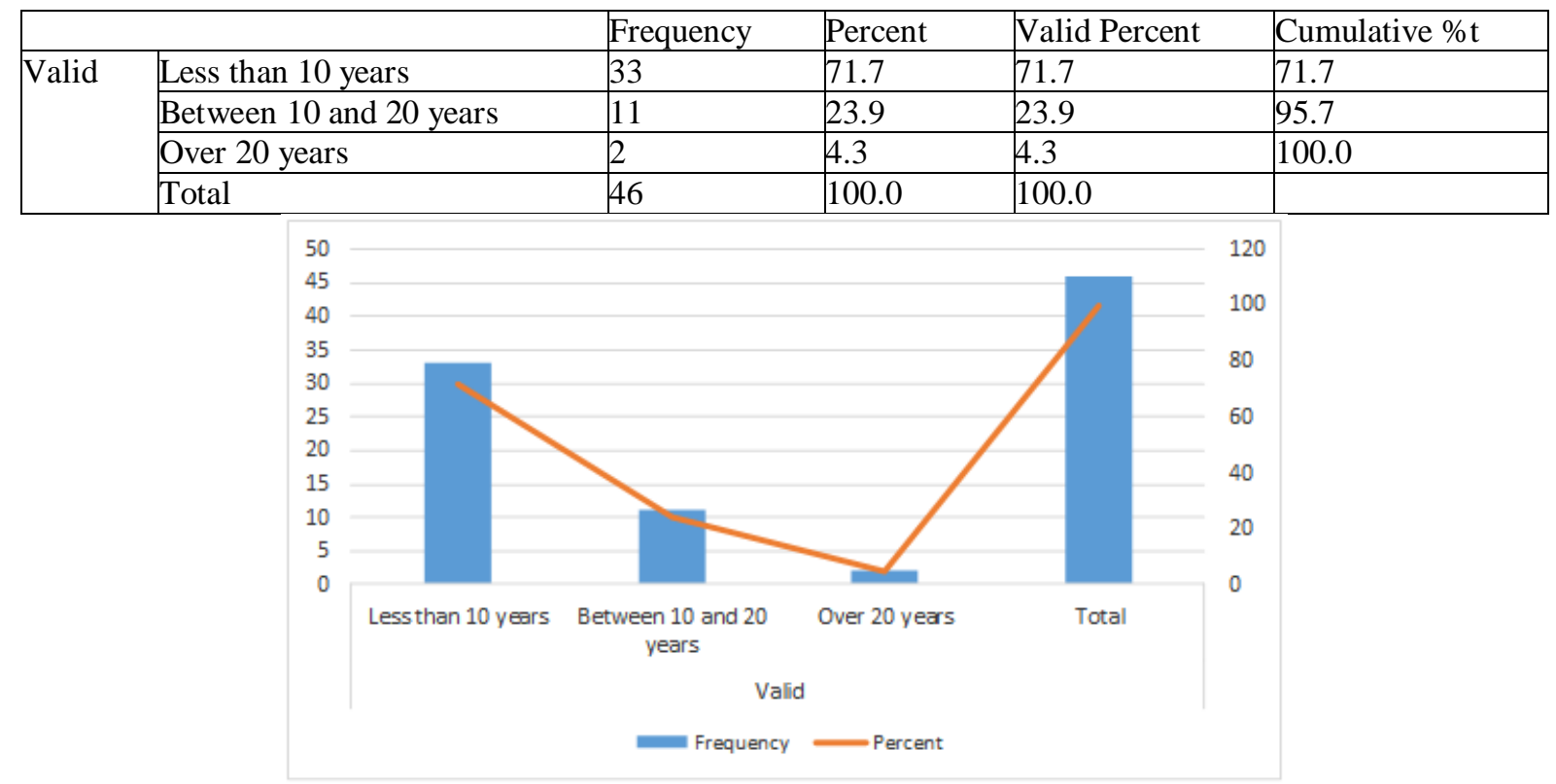

Figure9.1.5. Job Work Experience_of the Respondents

Source: Authors' own calculation from the questionnaire survey

\subsubsection{Job Position of the Respondents}

Regarding the current job positions of the respondents who participated in the study, the results indicate that of the 46 respondents, there were 9 (19.6) per cent) working as managers, 5 (10.9) per cent) working as assistant manager, 4 (8.7 percent) working as a head of department and other categories of employees represent the remain 60.9 percent

Table9.1.6. Current Job Position of the Respondents

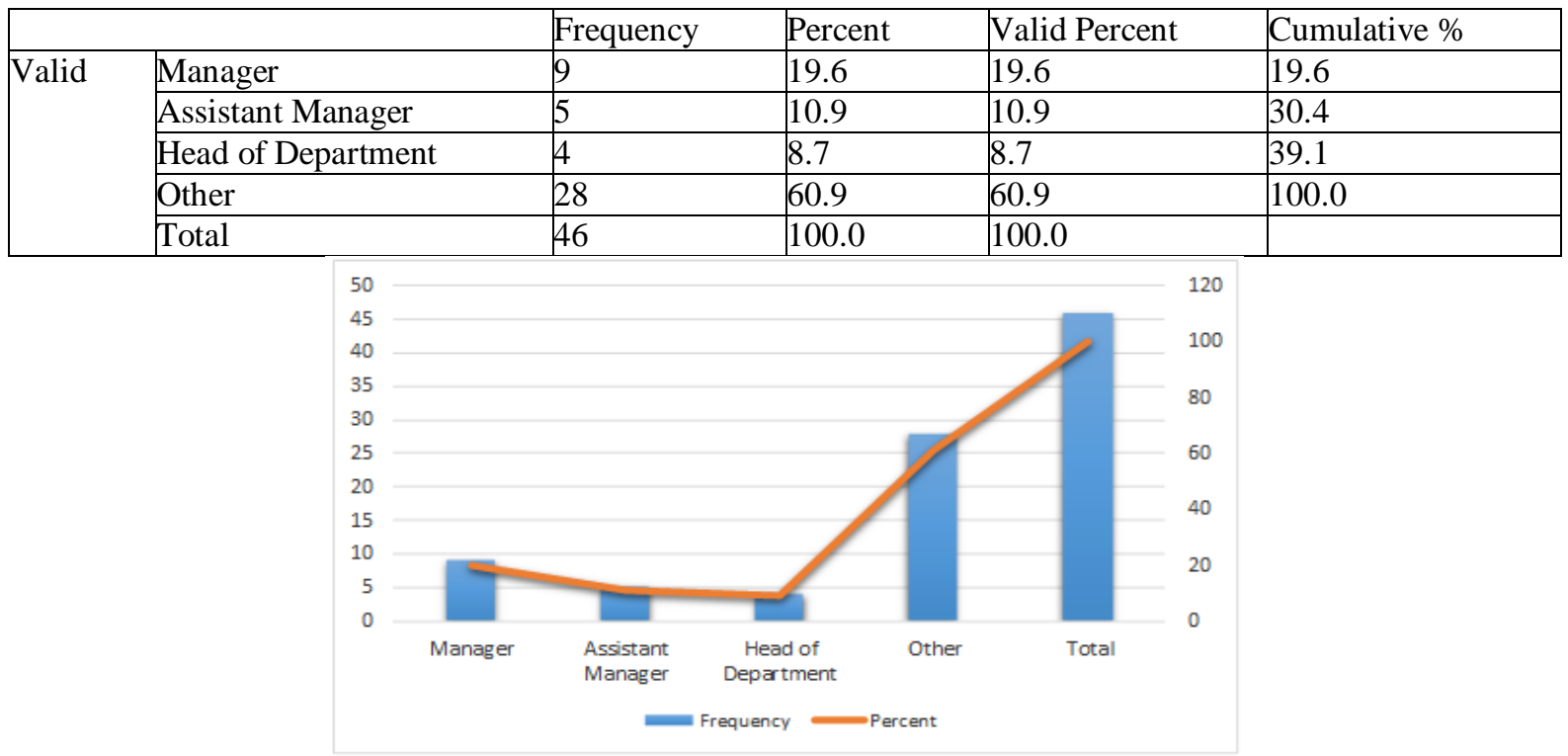

Figure9.1.6. Current Job Position of the Respondents 
Impact of Training on Employees' Performance: A Case Study of Selected Private Sectors Companies in Oman

Source: Authors' own calculation from the questionnaire survey

\subsection{Research-Specific Information}

In our survey, there are 7 factors associated with the impact of training on employees' performance and Table 9.2.1 demonstrates the results of our ranking.

As we can observe from the results of Table and Figure (9.2. 1), training programs play the most important role on enhancing their skills and performance of employees, followed by the factor which say training programs helped me to become more productive. In our survey, the effect of training on increasing the capacity to adopt new technologies and methods as well as increasing the speed of work achievements do not play an important role on employees' performance..

Table9.2.1. Impact of training Programs on Employees Performance

\begin{tabular}{|l|l|l|l|l|l|}
\hline S.No & Factors & Mean & St Dev & C.V \% & Rank \\
\hline 1 & Training programs enhance my skills and Performance & 4.630 & 0.734 & 15.853 & $\mathbf{1}$ \\
\hline 2 & $\begin{array}{l}\text { The training programs were relevant to the nature of my } \\
\text { work }\end{array}$ & 4.370 & 0.956 & 21.876 & $\mathbf{4}$ \\
\hline 3 & $\begin{array}{l}\text { The training programs helped me to become more } \\
\text { productive }\end{array}$ & 4.457 & 0.823 & 18.465 & $\mathbf{2}$ \\
\hline 4 & $\begin{array}{l}\text { Training help me to increase the speed of work } \\
\text { achievement }\end{array}$ & 4.196 & 0.674 & 16.063 & $\mathbf{7}$ \\
\hline 5 & I feel more creative after finishing training programs & 4.348 & 1.034 & 23.781 & $\mathbf{5}$ \\
\hline 6 & $\begin{array}{l}\text { Training programs helped me to solve some difficulties } \\
\text { that I face at my work }\end{array}$ & $\begin{array}{l}\text { Error! } \\
\text { Not at } \\
\text { valid } \\
\text { link. }\end{array}$ & 17.587 & $\mathbf{3}$ \\
\hline 7 & $\begin{array}{l}\text { Training programs increased my capacity to adopt new } \\
\text { technologies and methods }\end{array}$ & 4.239 & 0.892 & 21.043 & $\mathbf{6}$ \\
\hline
\end{tabular}

Source: Authors' own calculation from the questionnaire survey

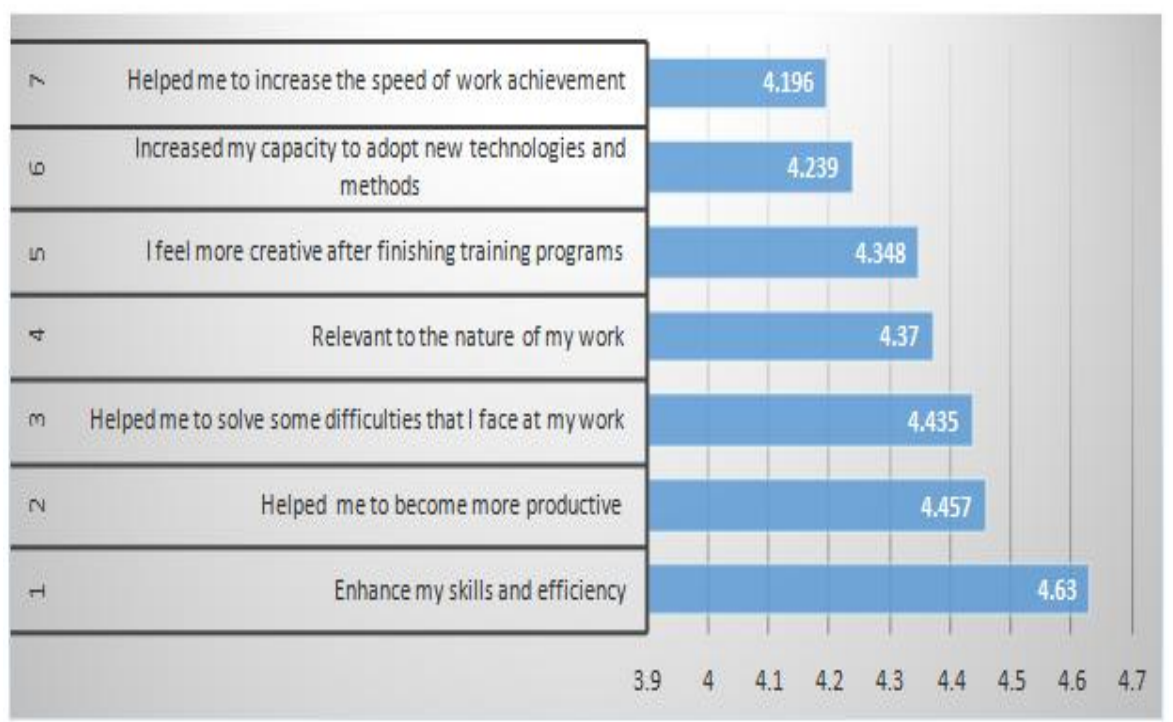

Figure9.2.1. Impact of training Programs on Employees Performance 
Impact of Training on Employees' Performance: A Case Study of Selected Private Sectors Companies in Oman

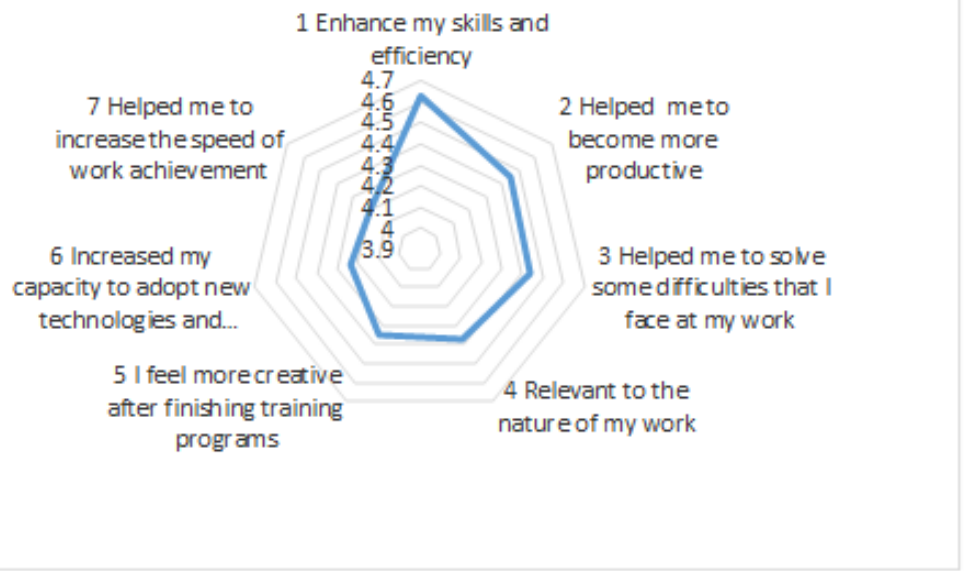

Figure9.2.1. Mean ranks of factors influenced by Training Programs

Table and Figure ( 9.2.2) show employees' views on company attitudes towards training programs ranked by mean, along with the standard deviation (StDev), and coefficient of variation (CV of each factor. The results presented in Table 2 and Figure 1 indicate that all 7 factors are influential, with some variations in terms of importance. The ranks of Employees' Views on Company attitudes towards training programs came logically. The believe that training is the best way to acquire new skills to their employees ranked first, followed by the fact that company has a mechanism to adjust and review training programs according to the need of training. The selection of training place, legists and trainers came in the last of the list and ranked 6 and 7 consecutively.

Table9.2.2. Employees' views on company attitudes towards training programs

\begin{tabular}{|c|c|c|c|c|c|}
\hline S.No & Factors & Mean & StDev & C.V \% & Rank \\
\hline 1 & $\begin{array}{l}\text { The selection of training place, legists and contents are } \\
\text { adequate and match up with my expectations }\end{array}$ & 3.130 & 0.987 & 31.529 & 6 \\
\hline 2 & My company usually select a well experienced Trainers & 2.783 & 0.756 & 27.169 & 7 \\
\hline 3 & $\begin{array}{l}\text { My company is always keen to follow the evaluation of } \\
\text { training programs }\end{array}$ & 3.935 & 1.1 & 27.956 & 3 \\
\hline 4 & $\begin{array}{l}\text { My company has a good mechanism to evaluate the } \\
\text { benefits of training programs }\end{array}$ & 3.543 & 0.883 & 24.919 & 5 \\
\hline 5 & $\begin{array}{l}\text { My company has a mechanism to adjust and review training } \\
\text { programs according to the need of training }\end{array}$ & 4.196 & 0.685 & 16.326 & 2 \\
\hline 6 & $\begin{array}{l}\text { The schedule of training programs in my company is } \\
\text { reviewed periodically to adjust to the new technological } \\
\text { development }\end{array}$ & 3.674 & 0.901 & 24.524 & 4 \\
\hline 7 & $\begin{array}{l}\text { My company believe that training is the best way to acquire } \\
\text { new skills to their employees }\end{array}$ & 4.283 & 0.78 & 18.213 & 1 \\
\hline
\end{tabular}

Source: Authors' own calculation from the questionnaire survey

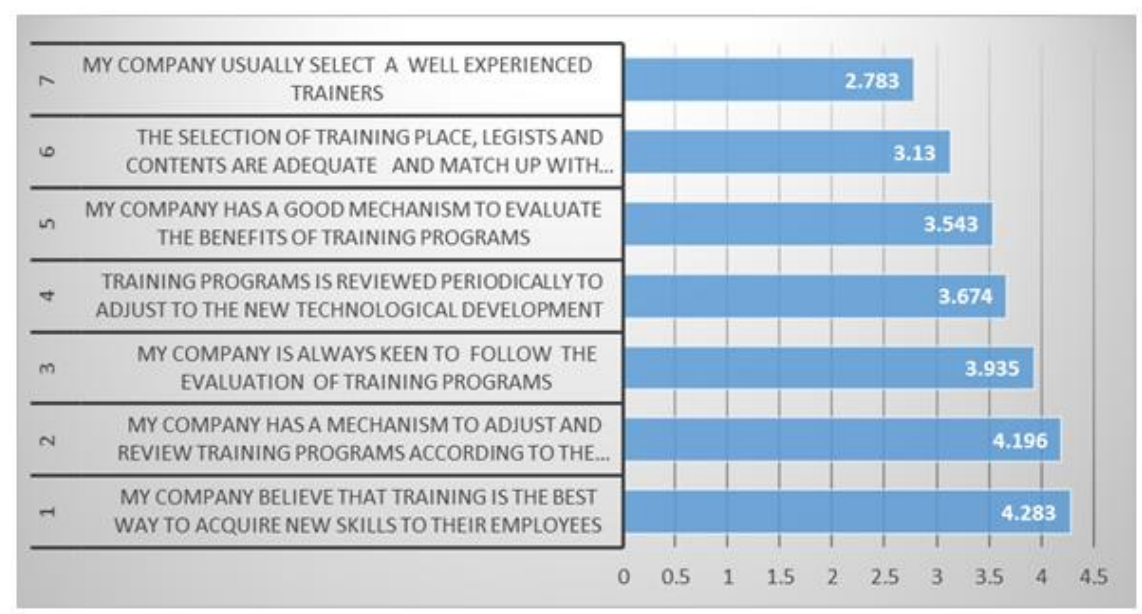


Figure9.2.2. Employees' views on company attitudes towards training programs

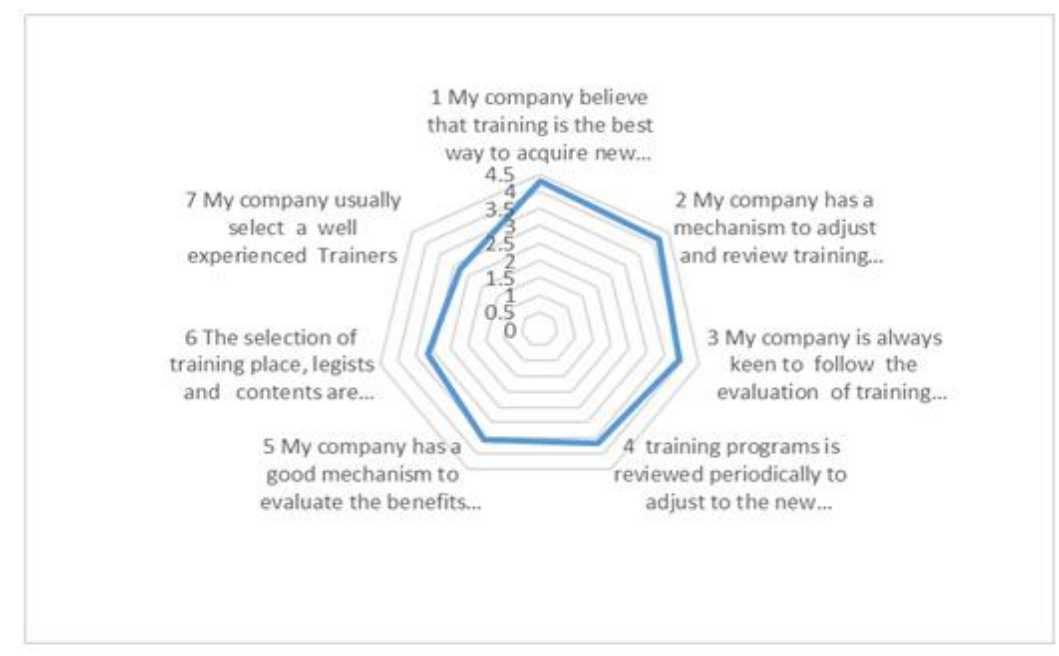

Figure9.2.2. Mean ranks of factors influenced by Training Programs

Table 9.2.3 summarized the answer to survey question "How many training Programs offered to you per year?" The results in Table 3 show that. The majority of respondents $32(69.6 \%)$ said that, 1 to 2 training programs offered for them per year., and 12 respondents who represent $26.1 \%$ of the sample said that their companies offer 2-3 training programs to them per year. Only 2 respondents said that their company offered for them more than 3 programs per year.

Table9.2.3. Number of training programs offered per year

\begin{tabular}{|l|l|l|l|l|l|}
\hline \multicolumn{2}{|l|}{ Programs } & Frequency & Percent & Valid Percent & Cumulative \% \\
\hline \multirow{4}{*}{ Valid } & $1-2$ & 32 & 69.6 & 69.6 & 69.6 \\
\cline { 2 - 6 } & $2-3$ & 12 & 26.1 & 26.1 & 95.7 \\
\cline { 2 - 6 } & $3+$ & 2 & 4.3 & 4.3 & 100.0 \\
\cline { 2 - 6 } & Total & 46 & 100.0 & 100.0 & \\
\hline
\end{tabular}

\subsection{Interviews}

The researchers conducted interviews with employees who work in private sectors to get more knowledge about the study. These interviews helped the researchers to collect different opinions about this topic. The researcher conducted interviews with employees who work in (Sohar Aluminum, Stomo Company (producing water and electricity for Oman), Suhail Bahwan Group (Holding) LLC, Ooredoo Company and Oman Formaldehyde Chemical Company).

\section{Questions:}

Q1. Does the company provide any kinds of training programs for its employees?

Q2. Do you think training programs can affect positively on employees' productivity and performances?

Q3. Is there any evaluation system for employees at institution after training programs conducted? How?

Q4. Is the implementation of the training policy monitored to ensure that it is practiced as prescribed?

Q5. Do your company allocate a reasonable budget for training and development?

Table9.3.1. Results of interviews

\begin{tabular}{|l|l|l|l|l|l|}
\hline Question & Sohar Aluminum & $\begin{array}{l}\text { Ooredoo } \\
\text { Company }\end{array}$ & $\begin{array}{l}\text { Stomo } \\
\text { Company }\end{array}$ & $\begin{array}{l}\text { Suhail Bahwan } \\
\text { Group } \\
\text { (Holding) LLC }\end{array}$ & $\begin{array}{l}\text { Oman } \\
\text { Formaldehyde } \\
\text { Chemical } \\
\text { Company }\end{array}$ \\
\hline Q1 & $\begin{array}{l}\text { Yes, lots and } \\
\text { divers training } \\
\text { programs offered } \\
\text { for employees }\end{array}$ & $\begin{array}{l}\text { We provides } \\
\text { many training } \\
\text { programs. In the } \\
\text { area } \quad \text { of }\end{array}$ & $\begin{array}{l}\text { Every we offer } \\
\text { many training } \\
\text { programs to } \\
\text { raise the skills }\end{array}$ & $\begin{array}{l}\text { Every year we } \\
\text { send our staff } \\
\text { for training } \\
\text { according to }\end{array}$ & $\begin{array}{l}\text { Yes, training } \\
\text { programs } \\
\text { offered }\end{array}$ \\
\hline
\end{tabular}


Impact of Training on Employees' Performance: A Case Study of Selected Private Sectors Companies in Oman

\begin{tabular}{|c|c|c|c|c|c|}
\hline & & $\begin{array}{l}\text { communication } \\
\text { and technology }\end{array}$ & $\begin{array}{ll}\text { of } & \text { our } \\
\text { employees }\end{array}$ & priority & \\
\hline $\mathrm{Q} 2$ & $\begin{array}{l}\text { Yes, sure training } \\
\text { programs can help } \\
\text { employees to } \\
\text { understand the } \\
\text { works and increase } \\
\text { their productivity }\end{array}$ & $\begin{array}{l}\text { Of course yes, } \\
\text { Without } \\
\text { training } \\
\text { programs the } \\
\text { company may } \\
\text { lose because } \\
\text { these kinds of } \\
\text { programs help } \\
\text { employees to } \\
\text { achieve } \\
\text { customers' } \\
\text { satisfaction }\end{array}$ & $\begin{array}{l}\text { Yes, Training } \\
\text { programs can } \\
\text { affect positively } \\
\text { on employees' } \\
\text { performances } \\
\text { and productivity }\end{array}$ & $\begin{array}{l}\text { Yes, training } \\
\text { programs can } \\
\text { improve } \\
\text { practical skills } \\
\text { of company's } \\
\text { employees but } \\
\text { these programs } \\
\text { not effect on the } \\
\text { productivity }\end{array}$ & $\begin{array}{l}\text { Yes, our } \\
\text { company send a } \\
\text { lot of amount } \\
\text { of money on } \\
\text { training in order } \\
\text { to enhance the } \\
\text { skills } \\
\text { productivity of } \\
\text { employees }\end{array}$ \\
\hline Q3 & $\begin{array}{l}\text { Yes, there is } \\
\text { evaluation system } \\
\text { inside } \\
\text { institution for staff } \\
\text { after training } \\
\text { program an and } \\
\text { conducted once a } \\
\text { year }\end{array}$ & $\begin{array}{l}\text { Yes, there is } \\
\text { evaluation } \\
\text { system in our } \\
\text { company for } \\
\text { employees after } \\
\text { training } \\
\text { programs and } \\
\text { conducted once } \\
\text { a year }\end{array}$ & $\begin{array}{l}\text { Yes, our } \\
\text { company has } \\
\text { own evaluation } \\
\text { system for its } \\
\text { staff after } \\
\text { training } \\
\text { programs and } \\
\text { conducted twice } \\
\text { a year }\end{array}$ & $\begin{array}{l}\text { Yes, there is an } \\
\text { evaluation } \\
\text { system in our } \\
\text { company to } \\
\text { evaluate } \\
\text { employees after } \\
\text { training } \\
\text { programs and } \\
\text { conducted once } \\
\text { a year }\end{array}$ & $\begin{array}{l}\text { Yes, there is } \\
\text { evaluation } \\
\text { system in our } \\
\text { company for } \\
\text { employees after } \\
\text { training } \\
\text { programs and } \\
\text { conducted three } \\
\text { times a year }\end{array}$ \\
\hline $\mathrm{Q} 4$ & $\begin{array}{l}\text { The policy of } \\
\text { training is well } \\
\text { minored }\end{array}$ & $\begin{array}{l}\text { Our have set } \\
\text { clear system for } \\
\text { implementing } \\
\text { and monitoring } \\
\text { training and } \\
\text { development } \\
\text { program }\end{array}$ & $\begin{array}{l}\text { HR in our } \\
\text { company has a } \\
\text { system of } \\
\text { monitoring the } \\
\text { implementation } \\
\text { of training } \\
\text { policy }\end{array}$ & $\begin{array}{l}\text { Our company } \\
\text { provides } 1-2 \\
\text { training courses } \\
\text { to each staff }\end{array}$ & $\begin{array}{l}\text { Yes, we have } \\
\text { well } \\
\text { stablishined } \\
\text { monitoring and } \\
\text { evaluation } \\
\text { policy for } \\
\text { training }\end{array}$ \\
\hline Q5 & $\begin{array}{l}\text { I think yes, training } \\
\text { is one of the top } \\
\text { priority in the } \\
\text { company and has a } \\
\text { separate fund to } \\
\text { finance it }\end{array}$ & $\begin{array}{lr}\text { Yes, funds ae } \\
\text { allocated for } \\
\text { internal and } \\
\text { external training }\end{array}$ & $\begin{array}{l}\text { Fund for } \\
\text { training are } \\
\text { considered inn } \\
\text { our budget } \\
\text { every year their } \\
\text { employees }\end{array}$ & $\begin{array}{l}\text { Yes, The } \\
\text { company know } \\
\text { the importance } \\
\text { of training and } \\
\text { allocate } \\
\text { reasonable } \\
\text { budget }\end{array}$ & $\begin{array}{l}\text { Yes, we have } \\
\text { percentage in } \\
\text { the budget } \\
\text { devoted } \\
\text { training every } \\
\text { year }\end{array}$ \\
\hline
\end{tabular}

\section{CONCLUSION AND POLICY RECOMMENDATION}

In the current paper, we investigated the impact of training programs on employees' performance in the private sector in Oman. Thus, we have taken a 5 cases of a private sector companies in Oman and analyzed the effect of training on the performance of their employees. Analytical and descriptive methodologies were used by employing data generated from an administrated questionnaire and direct interview. The findings shows the success of the training program on improving the employee's abilities, skills, productivity, efficiency. The results also showed that respondents agree with the relevance of the training program to the nature of their work.

The study also showed the employees' views on company attitudes towards training programs. The respondents confirmed that their companies believe that training is the best way to acquire new skills to them. Their companies has a clear policy for training through a clear mechanism for adjustment, review and evaluation of all training programs.

As a policy recommendation, it is vital for these companies in the private sector to raise the skills of their human assets by allocating reasonable funding for training. Training programs should be planned carefully by aligning the objectives of training with organizational objectives.

\section{REFERENCES}


[1] Abdelgadir N. and Abdel hafiz Elbadri (2001), Training Practices of Polish Banks: An Appraisal and Agenda for Improvement, Journal of European Industrial Training, Vol. 25, Issue 2/3/4, pp.69-79.

[2] Acton and Golden, 2002, Training: The Way to Retain Valuable IT Employees? Informing Science In SITE - "Where Parallels Intersect" June 2002

[3] Afshan sultana, Sobia irum, et al., Impact of Training on Employee Performance: A Study of Telecommunication sector in Pakistan, Interdisciplinary Journal of Contemporary Research in Business, October 2012 vol 4, no 6

[4] Cole, G. A (2002). Personnel and Human Resource Management 5th edition York Publishers., Continuum London, UK.

[5] Colombo and Stanca (2008). The Impact of Training on Productivity: Evidence from a Large Panel of Firms, International Journal of Manpower 35(8)

[6] Cooke F L., (2000), "Human Resource Strategy to improve Organizational Performance: A route for British firms", Working Paper No 9 EWERC, Manchester School of Management

[7] Daniels, Sharon (2003), "Employee Training: A Strategic Approach to Better Return on Investment", Journal of Business Strategy, Vol. 24, Issue 5, 2003, pp.39-42.

[8] Gasco, et.al (2004)." The Use of Information Technology in Training Human Resources: An E-learning Case Study", Rev. Econ. Stud 65, (1994) 155-173.

[9] Karia, N. (1999). The impact of TQM practices on employees' work related attitude. MBA Unpublished Research Report, Universiti Sains Malaysia

[10] Karia, N., \& Ahmad, Z. A. (2000). Quality practices that pay: Empowerment and teamwork. Malaysian Management Review, 35(2), 66-76. Karia

[11] Khaled N. Alshuwairek \&. Khaled N. Alshuwairek (2016), the leffectiveness of the training programs on employment performance : An empirical study at private sector companies in Saudi Arabia, International Journal of Business and Management Review Vol.4, Issue 9, pp.1-23,

[12] Kenney et al, (1992), Management Made Easy, 1st ed. South Carolina: Omron Publishers.Kanungo, R.N., (1982), "Measurement of job and work involvement", Journal of Applied Psychology, Vol; 77, Pp. 341349.

[13] Konings, Jozef and Vanormelingen, Stijn. The Impact of Training on Productivity and Wages: Firm Level Evidence (August 2009). LICOS Discussion Paper No. 244/2009, Available at SSRN: https://ssrn.com/abstract=1487468 or http://dx.doi.org/10.2139/ssrn.1487468

[14] Jihad, A (1999): "Evaluate the effectiveness of training programs in the private training centers from the perspective of the trainees", International Labor Organization 34, 79.

[15] McDowall, A. and Saunders, M.N.K. (2010) UK Managerees Conceptions of Training and Development. Journal of European Industrial Training, 34, 609-630. http://dx.doi.org/10.1108/03090591011070752

[16] Mozael, B. M. (2015) Impact of Training and Development Programs on Employee Performance International Journal of Scientific and Research Publications, 5(11), pp38-42

[17] Nischithaa \& Rao, (2014), The importance of training and development programmes in hotel industry, International Journal of Business and Administration Research Review, Vol.1, Issue.5, April-June, 2014

[18] Sepulveda, Facundo, Training and Productivity: Evidence for Us Manufacturing Industries (January 27, 2005). Available at SSRN: https://ssrn.com/abstract=830406 or http://dx.doi.org/10.2139/ssrn.830406

[19] Teresa Brannick, et al, (2002), Service Management Practice-Performance Model: A Focus on Training Practices, Journal of European Industrial Training, Vol. 26, Issue 8, pp.394-403.

[20] William, C. (1968), Training is a planned and ongoing process, New York, London. 


\section{AUTHORS' BIOGRAPHY}

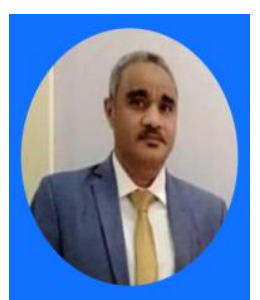

Dr. Sufian, Currently work as Assistant Professor of Economics at the Department of Public Law, and Head of Quality Assurance and Academic Accreditation Unit (QAAA) at the college of Law, Sultan Qaboos University. Before, he worked Assistant Professor of Economics Rustaq college of Applied Science, Minister of Higher Education (2012-2015). And Sur University College (2010-2012). He is also employed by Arab Planning Institute (API) based in Kuwait as Economic researcher. Dr sufian started his career as a lecturer and Head Department of Economics at Juba University based in Sudan (1996-2010).

Nabila Salim Hamed AL-Jahwari, she is a research scholar at the College of Applied Sciences, Ministry of Higher Education, Oman

Citation: Dr. Sufian Eltayeb Mohamed Abdel-Gadir, Nabila Salim Hamed AL-Jahwari. "Impact of Training on Employees' Performance: A Case Study of Selected Private Sectors Companies in Oman" International Journal of Managerial Studies and Research (IJMSR), vol 8, no. 8, 2020, pp. 29-41. doi: https:// doi.org/10.20431/2349-0349.0808004.

Copyright: (C) 2020 Authors. This is an open-access article distributed under the terms of the Creative Commons Attribution License, which permits unrestricted use, distribution, and reproduction in any medium, provided the original author and source are credited. 